\title{
USAHA PONDOK PESANTREN RIYADLUL JANNAH PACET MOJOKERTO DALAM MENGEMBANGKAN PEREKONOMIAN PESANTREN PERSPEKTIF ILMU EKONOMI SYARIAH
}

\author{
Oleh: \\ M Zidny Nafi' Hasbi \\ Universitas Islam Negeri Sunan kalijaga, Indonesia \\ vieq123@gmail.com
}

\begin{abstract}
:
Investment is funds or resources to obtain future profits. Investment does not have to be in the form of money, sometimes land, agricultural land, thoughts that can build a business, etc. Restaurants, farms, fisheries, villas, wedding organizations are some of the business investments owned by Pondok Pesantren Riyadlul Jannah. This paper aims to find out how the implementation of business investment in Pondok Pesantren Riyadlul Jannah, what are the hardships faced by the company Pondok Pesantren Riyadlul Jannah, and how to overcome these hardships in developing the economy of Pondok Pesantren Riyadlul Jannah. It used qualitative methods which include data sources, data collection techniques, and data analysis techniques.
\end{abstract}

Keyword: Pesantren, Investasi, Ekonomi, Syariah.

\section{A. Pendahuluan}

Islam telah menjelaskan tata cara bermuamalah yang baik dengan bermodal hukum dan etika, begitupula Rasulullah dalam hal perekonomian telah mengajarakan transaksi-transaksi perdagangan secara jujur, adil, dan tidak pernah membuat pelanggannya mengeluh dan kecewa. Ia selalu menepati janji dan mengantarkan barang dagangannya dengan standar dan kualitas sesuai dengan permintaan pelanggan. ${ }^{1}$ Sistem ekonomi Islam memiliki pijakan yang sangat tegas jika dibandingkan dengan sistem ekonomi liberal dan sosialis yang saat ini mendominasi sistem perekonomian dunia. Sistem ekonomi liberal lebih menghendaki suatu bentuk kebebasan yang tidak terbatas bagi individu dalam memperoleh keuntungan (keadilan distributif), dan sosialisme

1 Nur Chamid, Jejak Langkah Sejarah Pemikiran Ekonomi Islam, (Yogyakarta: Pustaka Pelajar, 2010), 26. 
menekankan aspek pemerataan ekonomi (keadilan yang merata), menentang perbedaan kelas sosial dan menganut asas kolektivitas. ${ }^{2}$

Dalam ekonomi Islam mengutamakan aspek hukum dan etika, yakni adanya keharusan menerapkan prinsip-prinsip hukum dan etika bisnis yang islami, etika tidak hanya berlaku pada sistem ekonomi, namun juga berlaku bagi individu yang mendirikan sebuah usaha. Wirausaha adalah seseorang yang memutuskan untuk memulai suatu bisnis, sebagai pewaralaba (franchisor) menjadi terwaralaba (franchisee). Memperluas sebuah perusahaan, membeli perusahaan yang telah ada, atau barangkali meminjam uang untuk memproduksi suatu produk baru atau menawarkan suatu jasa baru, serta merupakan manajer dan penyandang resiko. ${ }^{3}$

Sedangkan investasi merupakan komitmen atas sejumlah dana atau sumber daya lainnya yang dilakukan pada saat ini, dengan tujuan memperoleh keuntungan di masa akan datang. ${ }^{4}$ Namun tak sedikit bagi pelaku bisnis berinvestasi kepada usaha-usaha yang tidak mengandung ajaran dan ketentuan syari’at. Sehingga keuntungan yang diperoleh masih dipertanyakan halal dan haramnya, karena keuntungan yang diperoleh tidak berpedoman kepada atika bisnis islam.

Salah satu contohnya yang sering terjadi adalah investasi modal pada usaha milik orang cina (non muslim), disana akan banyak di jumpai etika mengambil keuntungan tanpa aturan yang telah di tetapkan oleh agama islam, sehingga apabila hal itu dibiarkan terus menerus, maka keuntungan yang diperoleh oleh investor termasuk keuntungan yang bathil. Berbeda halnya dengan usaha yang didirikan oleh Pondok Pesantren Riyadlul Jannah, Pacet, Mojokerto pimpinan K.H.Mahfudz Syaubari serta putra beliau Gus Yusuf, beliau merintis pesantren dengan berbekal wirausaha yang baik dan benar menurut ajaran agama islam. Pesantren Riyadlul Jannah tidak hanya mengkader dan menggodok santrinya menjadi kyai, da'i, ahli tafsir dan hadis serta pembaca kitab kuning. Namun lebih dari itu, dengan perantara jalur pendidikan mampu menghasilkan sumber daya manusia yang berpengetahuan luas, menguasai segala bidang ilmu pengetahuan dan mampu memberdayakan potensi santri dan masyarakat.

2 Abdul Aziz, Etika Bisnis Perspektif Islam, (Bandung: Alfabeta, 2013), 13.

3 Abas Sunarya, Sudaryono, dan Asep Saefullah, Kewirausahaan, (Yogyakarta: ANDI, 2011), 35.

4 Eduardus Tandelilin, Analisis Investasi dan Manajemen Portofolio, (Yogyakarta: BPFE, 2001), 3.

86 JURNAL LISAN AL-HAL 
Dalam kondisi yang demikian, Pesantren Riyadlul jannah melalui program-program yang diterapkan, dan banyak bidang usaha yang mampu didirikan dan bernaung dibawah kepemimpinan seorang kiai yang bertempat tinggal di pacet dan beromset 7.000.000.000. per bulan dalam rangka mengembangkan perekonomian pesantren, ada 42 usaha sebagai investasi dalam menegembangkan usaha pon-pes riyadlul jannah. Diantaranya, usaha kuliner ada 5 jenis di indonesia dan malasyia (Dapur Meriah, D`Kantin, Mr.J, Rumah Makan Puja Sera, M2M Bangil , Rajana Cafe ), lahan pertanian hingga mencapai hektaran (Kalimantan Barat, mojokerto, probolinggo, sidoarjo), Weeding Organition, Villa D`Ahsana Mansion Hills, rumah potong ayam, perikanan, peternakan. Berdasarkan apa yang uraikan diatas maka paper ini yang menjadi fokus permasalahannya bagaimana pelaksanaan dan jenis investasi usaha Pondok Pesantren Riyadlul Jannah dalam mengembangkan perekonomian pesantren serta apa saja hambatannya dalam pelaksanaan investasi?

\section{B. Metode Penelitian}

Paper ini menggunakan metode penelitian kualitatif yang merupakan salah satu prosedur penelitian yang dimaksudkan untuk mengungkapkan gejala secara holistik-kontekstual melalui pengumpulan data dari latar alami sebagai sumber langsung dengan instrumen kunci penelitian itu sendiri ${ }^{5}$. Metode kualitatif berusaha mengungkapkan berbagai keunikan yang terdapat dalam individu, masyarakat atau organisasi dalam kehidupan sehari-hari secara rinci, dan dapat dipertanggung jawabkan secara ilmiah. ${ }^{6}$

\section{Hasil dan Pembahasan}

\section{Hasil}

Paper ini penulis akan memparkan inti dari penelitian yang dilakukan, dalam bab ini Peneliti akan menyajikan dua hal yakni tentang paparan data yang telah peneliti dapatkan selama meneliti dan peneliti juga menghadirkan gambaran umum dari objek yang diteliti, kemudian penyajian yang selanjutnya peneliti mencoba membahas dengan semaksimal mungkin data data yang telah peneliti dapatkan.

${ }^{5}$ Ahmad Tanzeh, Pengantar Metode Penelitian (Yogyakarta: Teras, 2009),100.

6 Tatang M. Amirin, Menyusun Rencana Penelitian (Jakarta: PT. Raja Grafindo Persada, 1995), 95. 
a) Gambaran Umum Objek Penelitian

Pondok Pesantren Riyadlul Jannah adalah podok pesantren yang mandiri yang diasuh oleh seorang kiyai kharismatik beromset 7.000.000.000. dan beristri empat terletak didaerah Mojokerto tepatnya di tepi jalan raya Mojosari - Pacet Km 19 desa Pacet Kec. Pacet kabupaten Mojokerto di bawah kaki gunung Welirang.

Dalam Dalam usaha pondok ini juga dikenal dengan kemandiriannya dibandingkan kebanyakan pesantren lain didaerah Jawa Timur, banyak usaha yang diciptakan oleh pesantren ini, hingga saat ini usaha yang dimiliki mencapai 18 unit usaha dan diantara usaha usaha tersebut ada yang memiliki cabang hingga enam cabang, semua usaha usaha tersebut maju dan berkembang pesat bahkan sekarang omset yang dihasilkan mencapai Rp, 7.000.000.000. dan jumlah karyawan seluruhnya mencapai 2.500 -an orang. Dalam prakteknya, dalam usaha untuk mencatat nilai penanaman modal yang dilakukan dalam suatu tahun tertentu, yang digolongkan sebagai investasi (atau pembentukan modal atau penanaman modal).

b) Pelaksanaan Investasi PP Riyadlul Jannah Pacet Mojokerto

Pesantren dahulu memposisikan dirinya sebagai institusi pendidikan dan keagamaan, namun sejak tahun 1970-an beberapa pesantren telah berusaha melakukan reposisi dalam menyikapi berbagai persoalan sosial masyarakat, seperti ekonomi, sosial, dan politik. ${ }^{7}$ Dalam pengembangan ekonomi bagi para alumni santri. Pengurus pesantren dengan melibatkan para alumni santri menggalang sebuah usaha tertentu dengan tujuan untuk menggagas suatu usaha produktif bagi individu alumni, syukur bagai nanti keuntungan selebihnya dapat digunakan untuk mengembangkan pesantren. Prioritas utama tetap untuk pemberdayaan para alumni santri. Contohnya Pesantren mendirikan usaha ekonomi berupa koperasi yang bergerak dalam kegiatan simpan pinjam, perdagangan dan lain-lain. ${ }^{8}$

Investasi merupakan menanamkan atau menempatkan aset, berupa harta maupun dana pada suatu yang diharapkan akan memberikan hasil pendapatan atau meningkat nilainya di masa mendatang. ${ }^{9}$ Tentu saja

7 Nurcholish Madjid, Bilik-Bilik Pesantren Sebuah Potret Perjalanan, (Jakarta: Paramadina, 1997), 3.

8 Syamsudduha, Manajemen Pesantren: Teori dan Praktek, (Yogyakarta: Graha Guru, 2004,) 15-16.

9 Muhammad Firdaus, Sistem Keuangan dan Investasi Syari ah, (Jakarta: Renaisan Anggota IKPI, 2005), 12.

$88 \mid$ JURNAL LISAN AL-HAL 
investasi juga perlu diatur agar tidak terjadi over investment atau under investment. Pengaturan investasi modal yang efektif perlu memperhatikan beberapa faktor adanya usul-usul investasi, penaksiran aliran kas dari usul-usul investasi tersebut, evaluasi aliran kas tersebut, dan memilih proyek-proyek sesuai dengan ukuran tertentu. ${ }^{10}$ PP Riyadlul Jannah dalam mengembangkan usahanya adalah dalam bentuk salah satunya memberikan peluang dan kebebasan untuk mengendalikan nasib sendiri, memberi peluang melakukan perubahan, dan peluang untuk berperan aktif dalam masyarakat. ${ }^{11}$ Investasi bagi masyarakat merupakan kebutuhan sosial, dimana kebutuhan masyarakat yang kompleks, dengan persediaan sumber daya yang masih mentah, mengharuskan adanya investasi. ${ }^{12}$ Sebagaimana firman Allah S.W.T di dalam al-Qur`an:

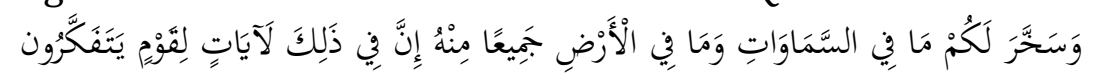

Artinya:"dan dia telah menundukkan untukmu apa yang dilangit dan apa yang dibumi semuanya, (sebagai rahmat) daripada-Nya. Sesungguhnya pada yang demikian itu benar-benar terdapat tanda-tanda (kekuasaan allah) bagi kaum yang berfikir"[Q.s. Al-Jatsiyah(45): 13] ${ }^{13}$

Berdasarkan prinsip al-Maal Maalullah bahwa kaidah dan norma syariah terkait dengan kegiatan investasi adalah legal secara syar'i, memperhatikan kemaslahatan sosial, korelasi antara profit, bertambahnya harta berbanding lurus, dan secara adil. ${ }^{14}$

Usaha-usaha yang menjadi investasi P.P. Riyadlul Jannah dalam mengembangkan perekonomian pesantren ada 2 jenis:

1) Investasi tahan lama

Investasi ini merupakan penanaman modal, aset, lahan, yang memiliki nilai sangat besar dari tahun ke tahun dan tidak akan pernah turun nilainya, hal ini juga dimiliki oleh perusahaan P.P. Riyadlul Jannah yaitu Rumah Makan, Wedding Organitation, dan Villa D'Ahsana Mainsion Hill. Adapun rumah makan P.P. Riyadlul Jannah memiliki 5 jenis kuliner makanan diantaranya adalah Dapur Mriah, Mr.J, Rajana Cafe, D`Kantin, M2M. Semua usaha ini dijalankan oleh karyawan dan santri P.P. Riyadlul

10 Saud Husnan, Manajemen Keuangan Teori dan Keterapan, (Yogyakarta: UPP AMP YKPN, 1998), 195.

11 Abas Sunarya, Sudaryono, dan Asep Saefullah, Kewirausahaan, (Yogyakarta: ANDI, 2011), 37.

12 Misbahul Munir, dan A. Djalaluddin, Ekonomi Qur 'Ani Doktrin Reformasi Ekonomi Dalam Al-Qur'an, (Malang: UIN Malang Press, 2006), 183-184.

13 Departemen Agama RI, Al-Qur'an \& Terjemahannya, (Tangerang: Lentera Hati, 2013), 499.

14 Misbahul Munir, dan A. Djalaluddin, Ekonomi ,. 194. 
Jannah, sampai sekarang jumlah rumah makan yang dimilki oleh P.P. Riyadlul Jannah ada 42 rumah makan yang terletak di indonesia dan malasyia.

Menurut norma investasi islam kegiatan invetasi harus memiliki legalitas secara syar $i,{ }^{15}$ artinya investasi tersebut tidak melanggar aturanaturan syari’at yang telah ditetapkan baik di dalam al-qur'an, hadist, ijma', dan qiyas. Investasi seperti ini sudah dilakukan oleh perusahaan P.P.Riyadlul Jannah yang banyak memiliki investasi usaha di berbagai daerah.

Sedangkan Wedding Organitation PP Riyadlul Jannah memiliki semacam tempat penyewaan baju pengantin pernikahan dan alat-alat kosmetik pengantin serta fotografer untuk acara pernikahan. Adapun latar belakang mendirikan preweeding adalah banyaknya santri yang menikah menjadi faktor utama merintis usaha preweeding, kelebihan preweeding milik P.P. Riyadlul Jannah dengan yang lain adalah pemilihan busana syar`i yang menutupi aurat perempuan, karena zaman sekarang banyak yang membuka usaha preweeding dengan busana yang tidak layak untuk dipakai dengan kata lain tidak sepenuhnya menutup aurat perempuan.

Dalam investasi islam harus berusaha mendapatkan profit dan keuntungan secara adil, dalam artian salah satu dari pihak yang melakukan transaksi tidak merasa dirugikan. ${ }^{16}$ Usaha seperti ini juga yang dilakukan oleh perusahaan Wedding Organitation milik P.P.Riyadlul Jannah.

Usaha D'Ashsana Mainsion Hill di Pesantren Riyadlul Jannah juga memiliki usaha pembangunan villa untuk dijual kepada orang-orang yang memiliki keinginan untuk tinggal di daerah yang sejuk dan jauh dari hiruk pikuk keramaian kota. Tujuan mereka adalah yang pertama untuk berlibur serta menjauh dari perkotaan yang sangat ramai. Demi menarik perhatian pembeli Villa D`Ahsana Mainsion Hill mematok harga 50 juta cash per slot villa. Namun disamping itu bukan hanya Villa D`Ahsana Mainsion Hill yang membangun villa, melainkan banyak orang yang memiliki lahan di pacet juga digunakan untuk membangun villa, agar supaya meraup banyak penghasilan dari penjualan villa.

PP Riyadlul Jannah tidak hanya investasi di Rumah Makan, Wedding Organitation, dan Villa D'Ahsana Mainsion Hill, namun juga investasi dalam bidang Pertanian dan Perikanan. Dalam menjalankan usaha tidak lepas dari aturan syari at islam sebagai rambu-rambu atau peringatan bagi

15 Ibid.

16 Ibid.

$90 \mid$ JURNAL LISAN AL-HAL 
orang yang menjalankan usaha, diantara rambu-rambu syari at menjelaskan larangan investasi dengan produksi yang membahayakan dan merugikan kehidupan. Aturan seperti ini juga sesuai dengan investasi pertanian perusahaan P.P.Riyadlul Jannah yang menghasilkan hasil panen yang sangat bermanfaat dan membantu kehidupan seperti padi, tembakau, sayuran, dll.

Pertanian merupakan tabungan bagi para pengusaha berjaga-jaga bila suatu saat usaha yang lain bangkrut, bisa ditutupi oleh hasil pertanian yang dimiliki. Dengan pertanian pengusaha mampu mengembangkan usahanya dengan pertanian, satu contoh bila hasil pertanian menurun tiap tahun. Maka lahan tersebut bisa dijadikan pembangunan toko atau villa yang sekiranya penghasilannya jauh lebih besar dari usaha pertanian.

Sedangkan dalam bidang investasi perikanan PP Riyadlul Jannah juga memiliki usaha perikanan, selain untuk di ekspor ke luar negeri juga untuk di masukkan ke rumah makan milik pesantren tersebut guna mengurangi dan meminimalisir pengeluaran yang ada. Perikanan milik pesantren Riyadlul Jannah juga mencapai 20 ton perminggu, perikanan itu dikelola oleh santri dan mahaputra P.P. Riyadlul Jannah.

2) Investasi tidak tahan lama

Investasi tidak tahan lama adalah penanaman aset, modal, dan lahan yang nilainya akan turun dari tahun ke tahun dikarenakan ada produk yang lebih bagus, dan berkembangnya zaman. Investasi seperti ini juga dilakukan oleh perusahaan P.P. Riyadlul Jannah diantaranya yaitu transportasi, dan teknologi

3) Investasi Vertikal

Investasi ini merupakan penanaman aset atu modal kepada Allah SWT agar supaya memperoleh berkah di dalam menjalankan usahanya dan hidupnya, karena orang berusaha harus memiliki 4 hal, Daya, Data, Dana, dan Do'A. Prinsip yang terakhir inilah yang jarang diterapkan oleh pengusaha. Investasi seperti ini juga yang dilaksanakan oleh perusahaan P.P.Riyadlul Jannah. Perusahaan tersebut selalu menyisakan laba bersihnya $10 \%$ untuk di infaqkan kepada masjid yang membutuhkan, orang-orang yang yang tidak berkecukupan, serta menyantuni anak yatim. Pimpinan perusahaan P.P.Riyadlul Jannah meyakini bahwa apabila kita bersedekah 1 maka allah SWT akan membalasnya dengan 10 kali lipat. Hal inilah yang menjadi faktor secara tidak langsung berkembang pesatnya perusahaan Riyadlul Jannah. 
c) Hambatan Pelaksanaan Investasi Perusahan PP Riyadlul Jannah Serta dan bagaimana solusinya

Salah satu fungsi dan peran pesantren adalah pemberdayaan ekonomi umat. Pengembangan wirausaha menjadi salah bidang yang penting untuk dikelola. Mengacu pada peran dan fungsi pesantren yang diemban tersebut, setidaknya ada tiga problem mendasar dalam pengembangan unit usaha di pesantren yang harus disadari bersama dan segera dicari solusinya yaitu sumber daya manusia (SDM), kelembagaan, dan Inovasi jaringan. Dalam hal inovasi jaringan pesantren berperan penting untuk membina hubungan dengan institusi lain adalah untuk memahami eksistensinya sebagai agent of development. Sebab, untuk menjadi agen perubahan dan pemberdayaan, ada beberapa persyaratan yang harus dipenuhi, antar lain: wawasan, komunikasi, kekuasaan/kekuatan, politik, dan modalitas ekonomi. Dengan jaringan dan kerjasama yang dijalin, pesantren diharapkan mampu meningkatkan komunikasi, wawasan, dan kekuatan yang dimilikinya. ${ }^{17}$

Adapun yang menjadi hambatan berkembangnya perusahaan Riyadlul Jannah adalah eskternal dan internal. Hambatan secara eksternal adalah kendala yang datangnya dari luar dan ini menjadi masalah terbesar dalam menjalankan sebuah usaha, yang berupa ilmiah dan non ilmiah baik secara ilmiah adalah kendala yang bisa dilihat secara indrawi oleh pengusaha, baik itu datangnya dari pesaing atau orang lain yang tidak senang dengan usaha yang kita dirikan. Dan secara non ilmiah adalah kendala yang tak bisa dilihat oleh alat inderawi, namun perannya juga sangat besar dalam menurunkan perkembangan perusahaan. Sehingga harus ada solusi untuk mengatasi hambatan eksternal yang non ilmiah seperti ini. Hal ini juga yang dirasakan oleh perusahaan Riyadlul Jannah dalam mengelola investasi usaha milik P.P. Riyadlul Jannah. Contoh berupa sihir dan lain semacamnya yang dapat membuat perusahaan tersebut bangkrut dan tidak berkembang lagi. Adapun solusinya antara keduanya adalah bersaing secara sehat dengan perusahaan lain sesuai dengan ajaran Islam dan menbetuk sacara tim dengan bertujuan membandingkan harga produk perusahaan Riyadlul Jannah dengan pesaingnya. Serta membentuk Tim Pemburu Hantu, tujuannya adalah menolak hambatan non ilmiah tersebut. Karena seandainya hal itu dibiarkan, maka menjadi masalah besar bagi perusahaan Riyadlul Jannah itu sendiri.

17 Sulton, Manajemen Kewirausahaan Kependidikan, (Malang: Universitas Negeri Malang, 2003), 233.

92 JURNAL LISAN AL-HAL 
Sedangkan hambatan secara internal adalah kendala yang datangnya dari dalam, yang dapat membuat loyalitas perusahaan tersebut menurun dan itu juga dialami oleh perusahaan Riyadlul Jannah, yang merupakan diantaranya karyawan dan dana. Adapun karyawan menjadi hambatan secara internal bagi perusahaan Riyadlul Jannah, karena karyawan juga penentu dalam kemajuan perusahaan itu sendiri. Akan tetapi perusahaan riyadlul jannah menemukan solusi untuk mengatasi masalah internal tersebut yaitu dengan melakukan evaluasi dengan para karyawan serta manajer perusahaan setiap bulannya, agar mengetahui titik kelemahan hambatan internal perusahaan Riyadul Jannah tersebut. Sedangkan hambatan secara dana juga menjadi hambatan internal yang sangat serius bagi perusahaan Riyadlul Jannah, tanpa dan usaha tidak akan pernah berjalan. Namun kendala seperti ini masih dianggap mudah di atasi oleh perusahaan Riyadlul Jannah dibandingkan hambatan internal karyawan, karena perusahaan Riyadlul Jannah banyak memiliki investorinvestor kaya yang siap membantu apabila perusahaan tersebut kekurangan dana. Solusi untuk mengatasi masalah itu adalah dengan menarik dan mencari investor-investor tambahan agar supaya mendapatkan suntikan dana dari mereka.

\section{Pembahasan}

Kaitannya paper ini dengan penelitian terdahulu yang dilakukan oleh Riana Fauzia Saputri yang berjudul "Analisis Pengaruh Investasi Sumber Daya Manusia Terhadap Pertumbuhan Ekonomi Di Jawa Tengah", skripsi ini sama-sama menjelaskan tentang investasi. Namun yang menjadi titik perbedaan adalah objek penelitian yaitu investasi sumber daya manusia dengan investasi umum, serta investasi pertumbuhan ekonomi provinsi dengan investasi usaha pesantren. ${ }^{18}$ Dan yang dilakukan oleh Alfian Wahyu Fauzan yang judul skripsi yang di teliti yaitu "Analisis Pengaruh Investasi, Tenaga Kerja dan Tingkat Pendidikan Terhadap Pertumbuhan Ekonomi" (Studi Kasus: Kabupaten/Kota di Provinsi Jawa Tengah Tahun 2009-2013) skripsi ini sama-sama menjelaskan tentang investasi. Namun yang menjadi titik perbedaan adalah metode penelitiannya menggunakan penelitian kuantitatif. Sementara penulis menggunakan penelitian kualitatif. ${ }^{19}$

18 Riana Fauzia Saputri, skripsi, Analisis Pengaruh Investasi Sumber Daya Manusia Terhadap Pertumbuhan Ekonomi Di Jawa Tengah, Universitas Diponegoro, Semarang, 2014.

19 Alfian Wahyu Fauzan, Skripsi, Analisis Pengaruh Investasi, Tenaga Kerja, Dan Tingkat Pendidikan Terhadap Pertumbuhan Ekonomi (Studi Kasus: Kabupaten/Kota Di 


\section{Simpulan}

Kesimpulan dari paper ini adalah pelaksanaan investasi usaha P.P. Riyadlul Jannah mengikuti cara berdagangnya rasulullah SAW dengan bermodal 4 hal yaitu daya, (kemampuan yang dimiliki), kemudian data, (hasil yang diperoleh dari daya tersebut), selanjutnya dana, (banyaknya modal yang dimiliki), serta yang terakhir adalah do`a, (ikhtiyar dan tawakkal kepada Allah SWT), sementara investasi yang dimiliki oleh perusahaan Riyadlul Jannah ada 3 jenis yaitu, pertama investasi tahan lama meliputi Rumah Makan, Wedding Organitaion, Villa D`Ahsana Mainsion Hill, Pertanian, dan Perikanan. Kemudian yang kedua investasi tidak tahan lama meliputi Transoprtasi dan Tekhnologi. Dan yang ketiga investasi vertikal artinya penanaman aset atau modal kepada Allah SWT seperti berinfaq kepada masjid, menyantuni anak yatim, serta mengeluarkan $10 \%$ dari laba yang diperoleh untuk orang yang berhak, agar supaya memperoleh berkah di dalam menjalankan usahanya dan hidupnya, karena orang berusaha harus memiliki 4 hal, Daya, Data, Dana, dan $D o{ }^{`} A$.

Sedangkan kendala yang dihadapi adakalanya secara internal dan eksternal. Cara menanggulanginya adalah menyikapi dan mencegah datangnya hambatan yang akan menghadang, bila secara eksternal berupa pesaing, lahan kurang strategis, dan harga pesaing, solusi yang tepat adalah menunjukkan kualitas yang terbaik dibandingkan dengan pesaingnya, kemudian dengan cara memanfaatkan lahan yang ada jangan sampai ada yang kosong, memberikan harga yang terjangkau dan murah dibandingkan pesaingnya. Dan apabila secara eksternal non ilmiah, cara menanggulanginya harus dihadapi dengan non ilmiah juga, artinya dengan spritual. Sementara bila hambatannya secara internal seperti kurangnya dana dan dari pihak karyawan sendiri, solusinya adalah mencari investorinvestor kaya untuk mencari dana segar, kemudian melakukan evaluasi setiap bulannya dengan karyawan dan para manajer.

\section{DAFTAR PUSTAKA}

Amirin, Tatang M. Menyusun Rencana Penelitian, Jakarta: PT. Raja Grafindo Persada. 1995.

Aziz, Abdul, Etika Bisnis Perspektif Islam, Bandung: Alfabeta. 2013.

Provinsi Jawa Tengah Tahun 2009-2013), Universitas Diponegoro, Semarang, 2015.

94 JURNAL LISAN AL-HAL 
Chamid, Nur, Jejak Langkah Sejarah Pemikiran Ekonomi Islam, Yogyakarta: Pustaka Pelajar. 2010.

Departemen Agama RI. Al-Qur'an \& Terjemahannya, Tangerang: Lentera. 2013

Fauzan, Alfian Wahyu, Skripsi. Analisis Pengaruh Investasi, Tenaga Kerja, Dan Tingkat Pendidikan Terhadap Pertumbuhan Ekonomi (Studi Kasus: Kabupaten/Kota Di Provinsi Jawa Tengah Tahun 2009-2013), Universitas Diponegoro, Semarang. 2015.

Firdaus, Muhammad, Sistem Keuangan dan Investasi Syari ah, Jakarta: Renaisan Anggota IKPI. 2005.

Husnan, Saud, Manajemen Keuangan Teori dan Keterapan, Yogyakarta: UPP AMP YKPN. 1998.

Madjid, Nurcholish, Bilik-Bilik Pesantren Sebuah Potret Perjalanan, Jakarta: Paramadina. 1997.

Munir, Misbahul dan A. Djalaluddin, Ekonomi Qur'Ani Doktrin Reformasi Ekonomi Dalam Al-Qur'an, Malang: UIN Malang Press. 2006.

Saputri, Riana fauzia, Analisis Pengaruh Investasi Sumber Daya Manusia Terhadap Pertumbuhan Ekonomi Di Jawa Tengah, Universitas Diponegoro, Semarang. 2014.

Sulton, Manajemen Kewirausahaan Kependidikan, Malang: Universitas Negeri Malang. 2003.

Sunarya, Abas, Sudaryono, dan Asep Saefullah, Kewirausahaan, Yogyakarta: ANDI. 2011.

Syamsudduha, Manajemen Pesantren: Teori dan Praktek, Yogyakarta: Graha Guru. 2004.

Tandelilin, Eduardus, Analisis Investasi dan Manajemen Portofolio, Yogyakarta: BPFE, 2001.

Tanzeh, Ahmad, Pengantar Metode Penelitian, Yogyakarta: Teras. 2009. 
"Pengaruh Spiritual Quotient"

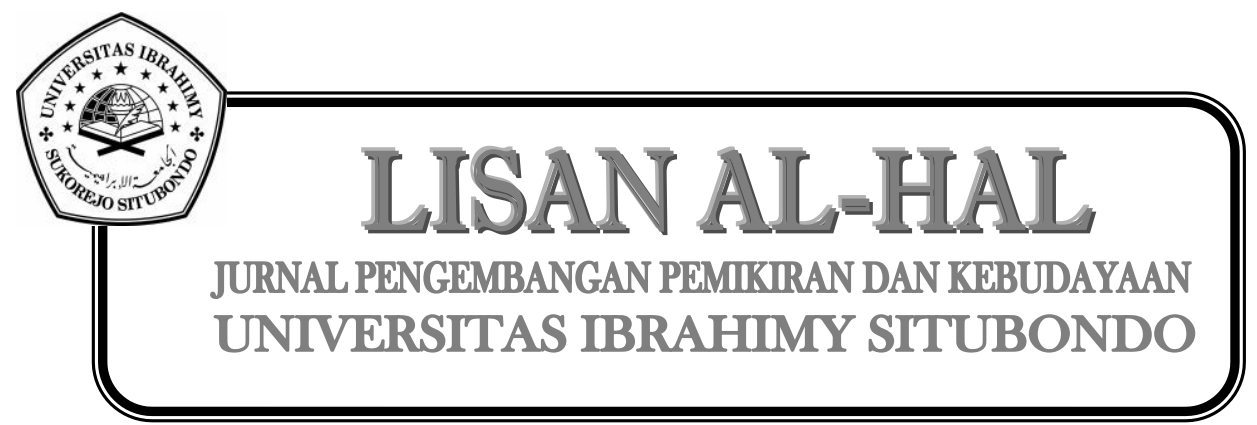

96 JURNAL LISAN AL-HAL 